\title{
Türkiye'deki Bazı Hemoglobin Varyantları Ve Bunların Fizikokimyasal Özelliklerinin Araştırılması
}

\author{
Research On Some Hemoglobin Variants And On \\ Their Physicochemical Properties of Turkey
}

Gazanfer BíNGöL*

\author{
Gülesi AYANOĞLU*
}

\section{GIRIŞ}

Hemoglobinopatiler, bütün dünyaya yaygın kalıtsal hastalılardır. Bunların dünyanın belirli bölgelerinde yoğunlaşmış olarak bulundukları ve çeşitli etnik gruplara özgü oldukları bilinmektedir. Bu bakımdan, hemoglobinopatilerin dağılım ve kaynaklarının incelenmesi, gerek sağlık, gerek antropoloji bilimleri açısından büyük önem taşımaktadır.

Türkiye, coğrafik konumu ve tarihi özellikleri nedeniyle, dünyanın çeşitli bölgelerinde saptanan hemoglobinopatilerin hemen hemen tümünün örneklerini içinde barındıran sayılı ülkelerden biridir. Türkiye, bir Akdeniz ülkesi olarak, talasemi hastalığının yaylma kuşağı içinde kalmaktadır (1). Türklerin, orak hücre karakterini Yunanlılardan ve hemoglobin E karakterini Orta Asya'dan aldıkları ileri sürülmüsstür (2). Bazı yazarlara göre de Türkler, hemoglobin C ve hemoglobin D genlerini Afrika ve Orta Doğu halklarından almışlardır (3). Güney anadolu bölgesinde yaşamakta olan ve "Eti Türkleri" adı verilen grupta görülen hemoglobin S ve hemoglobin E karakterlerinin, zenciler ve Hindistan veddoidleri ile karışma sonucu ortaya çıktığı ileri sürülmektedir $(4,5)$.

Biz bu çalşmamızda, Türkiye'nin bu yönden önemli bazı bölgelerinde hemoglobinopatilerin dağılımı ve kaynaklarını saptamayı

Ecz.Gülesi Ayanoğlu’nun "Türkiye'deki Bazı Hemoglobin Varyantları ve Bunların Fizikokimyasal Özelliklerinin Arastirnlmast" isimli Doktora Tezinin özetidir. Sinav Tarihi : Haziran 1975 Redaksiyona Verildiği Tarih: 26 Ocak 1976.

* Biyokimya Kürsüsü, Eczacıllk Fakültesi, Ankara Üniversitesi. 
amaçladık. Bu amaçla çeşitli kaynaklardan elde edilen kan örnekleri üzerinde sistematik bir araştırma yapmaya karar verdik. Güney anadoluda, Içel iline bağlı üç Eti Türkü köyünde, çeşitli hemoglobinopatilerin dağılımlarını saptadık. Ayrıca bu çalışmayı çocuklar üzerinde yaparak, Eti Türklerinde oldukça yoğun olarak bulunan orak hücre geninin gelecek nesillerdeki dağılımı konusuna açıklık getirmeyi amaçladık.

Gerek $\alpha$-talasemi ve diğer $\gamma$-zinciri varyantlarının sebeb olduğu hastalıklar, gerek $\beta$-talasemi hastalığının erken teşhisinde, göbek kordonları üzerinde çalışılması zorunlu olmaktadır. Biz bu nedenle araştırmamızın bir bölümünü de kordon kanları üzerinde yapmaya karar verdik.

Ayrıca bu çalı̧mada, Eti Türkleri üzerinde yapılan sistematik araştırma sonucu ortaya çıkarılan yeni bir albumin variantının bazı fizikokimyasal ve genetik özellikleri saptandı.

\section{E N E K I I M}

\section{MATERYAL}

1. Içel yöresinde Eti Türklerinin yaşadıkları üç yerleşme bölgesinde 7-11 yaş grubundaki 369 çocuktan kan örneği alındı. Örnekleme seçimsiz olarak ve akrabalık ilişkileri gözönüne alınmadan yapıldı. Seçilen yerleşme bölgesi ve alınan örnek sayısı aşağıda gösterilmiştir :

\begin{tabular}{lrrrr} 
Yerleşme bölgesi & & Nufus & & Örnek sayısı \\
\cline { 1 - 1 } Adanalığlu & & 2000 & & 91 \\
Karacailyas & & 2000 & & 126 \\
Karaduvar & & 7000 & & 152
\end{tabular}

Kan alımı, materyali saklama ve ulaşım gibi zorluklar gözününe alınarak materyal toplama işlemi özel bir yöntemle yapıldı. Bu yönteme göre, kan örnekleri parmaktan heparinli kılcal tüplere toplandı.

Her çocuktan ortalama $100 \mu 1$ kan örneği alındı. Örnekler alındıkları gün santrifüj edilerek plazmalarından kurtarıldı, Konsantre alyuvarlar $4 \mathrm{C}^{\circ}$ de Ankara'ya getirilerek hemoglobin solusyonları hazirlandi. 
2. Göbek kordonu kanı örnekleri Ankara Doğumevinden sağlandi. Doğumdan hemen sonra plasentadan alınan örnekler, 1/5 hacım \% 3.2 lik sodyum sitrat solusyonu ihtiva eden şişelere toplandı. Toplam 90 adet kordon kamı örneği alındı.

5. Eti Türklerinde kan proteinlerinin analizi için, hemoglobinopati araştırılmașı yapılan kan örneklerinin plazmaları kullanıldı. Kan örnekleri alındıkları gün santrifüj edilerek plazmaları alındı ve $-20 \mathrm{C}^{\circ}$ de saklandı.

\section{YÖNTEM}

\section{Eti Türkleri Û́zerinde Yapılan Çalışmalar}

a. Rölatif kan hacımlarının ölçülmesi:

Kan örneklerinin rölatif kan hacımları alındıkları gün "Cellokrit" ölçüm aletinde ölçüldü.

b. Hemolizatların hazırlanmas1:

369 kan örneğinin hemolizatlarının hazırlanması için, çalışma şartlarına uygun bir mikrohemoliz yöntemi kuruldu. Bu yönteme göre kan örneklerinin mikro tüp içinde hemolizleri sağlandı. Plazmalarından kurtarılan konsantre alyuvarlar, mikrotüp içinde 1 hacım hemoliz yapıcı çözelti ( $1 \mathrm{~g}$ disodyum EDTA $+0.5 \mathrm{~g}$ saponin/ $100 \mathrm{ml}$ distile su) ile karıştırıldı (6). Üzerine 0.5 hacım toluen eklendi ve $4 \mathrm{C}^{\circ}$ de 18 saat bekletildi (7) Santrifüj ile hücre artıkları ve toluen tabakalarından kurtarilarak berrak hemoglobin solusyonu elde edildi.

c. Selüloz asetat elektroforezi:

369 hemolizatta anormal hemoglobinlerin teşhisi için bazik ortamda yapılan sellüloz asetat elektroforezi metodu kullanıldı. (8). $\% 2$ konsantrasyondaki hemolizatlar, Sepraphore III (Gelman Instrument Company) selüloz poli asetat şeritleri kullanılarak, Tris + disodyum EDTA + borik asit (pH: 9.1) tamponunda, 350 voltta 3.5 saat süre ile elektroforezde yürütüldü. Elektroforegramlar amidoblack 10 B boyası ile boyanarak yıkandı ve berraklaştırıldı (9). Anormal hemoglobin bantlarmm miktar tayinleri optik dansitometrede (Loeble-Joyce Densitometre) ince tabaka aksesuvarı kullanılarak yapıld. 
d. Agar jel elektroforezi:

Kan örneklerinde talesemi ve fetal hemoglobin teşhisi için ZUELZER ve arkadaşlarının asit ortamdaki agar jel elektroforezi kullanıldı (10).

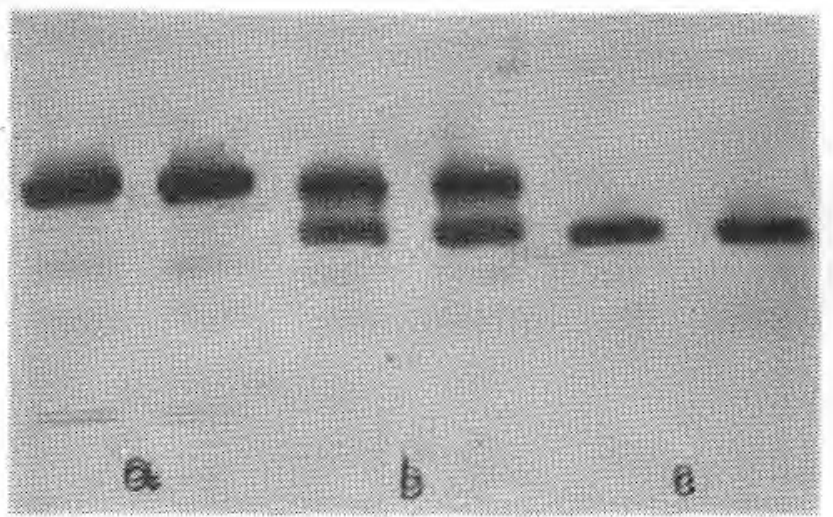

Resim 1. Hemoglobinlerin selüloz asetat elektroforezi ile ayırımı. a. normal hemolizat, b. orak hücre karakteri, c. orak hücre anemisi.

Kan örneklerinde $\alpha$-talasemi ve $\beta$-talasemi teşhisi için ZUELZER ve arkadaşlarının asit ortamda yapılan agar jẹl elektroforezi kullanildı (10). Hemolizatlar, \% 1 lik agar jelinde (Bacto-Difco agar), 75 mili amper akım şiddetinde 14 saat elektroforezde yürütüldü. o-dinasidin boyası ile boyanarak (11) teşhisler yapıldı. Bu metotla hemoglobin $\mathrm{A}$, hemoglobin $\mathrm{S}$ ve hemoglobin $\mathrm{F}$ in ayırımını yapmak mümkün oldu (Resim 2).

e. Hematolojik deneyler:

Orak hücre karekteri taşıyan örneklerde DALAND CASTLE metoduna göre oraklaşma deneyi yapıldı (12). Bir lam üzerine bir damla kan, bir damla izotonik hale getirilmiş indirgen çözelti (11.0 $\mathrm{g}$ askorbik asit $+0.55 \mathrm{~g}$ sodyum meta bisulfit $+3.25 \mathrm{~g}$ sodyum karbonat $/ 100 \mathrm{ml}$ ). ile karıştırıldı. Mikroskopta çeşitli zaman aralıklarında alyuvarların oraklaşması gözlendi (Resim 3).

Ayrica kan örneklerinin mikroskop ile incelenmesinde, talasemi ve diğer bazı hemoglobinopatilere özgü "hedef hücreleri" ve "hipokromi" gibi hematolojik bulgular saptand. 


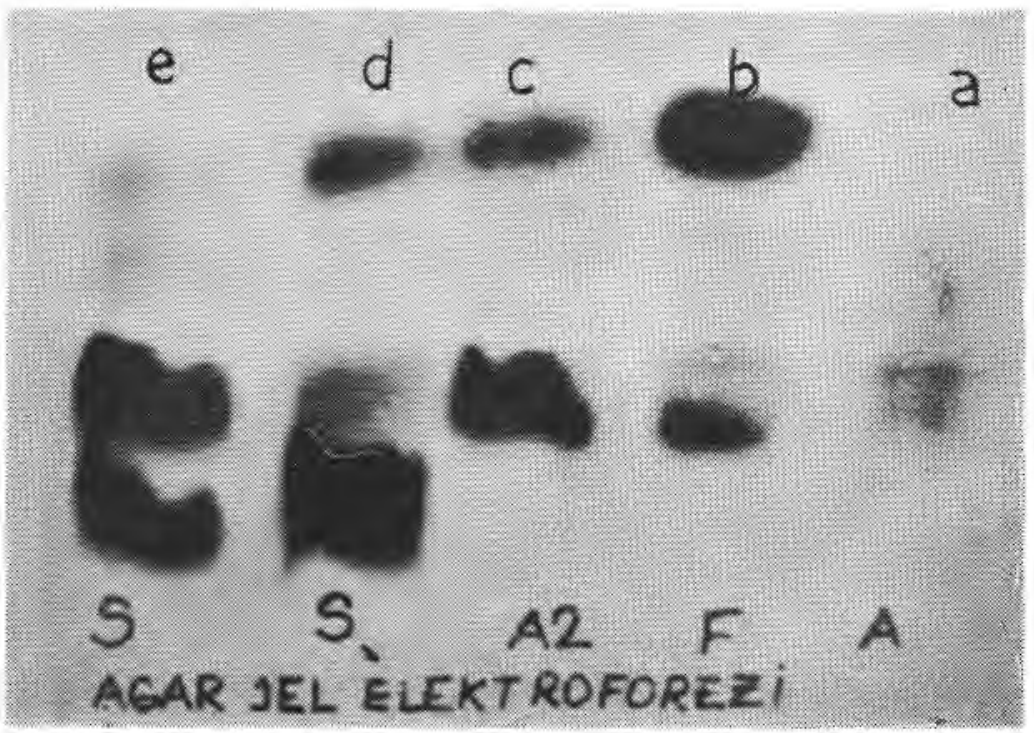

Resim 2. Hemoglobinlerin agar jel elektroforezinde ayırımı, a. Normal hemolizat, b. talasemi major, c. talasemi minör, d. orak hücre anemisi, e. orak hücre karakteri

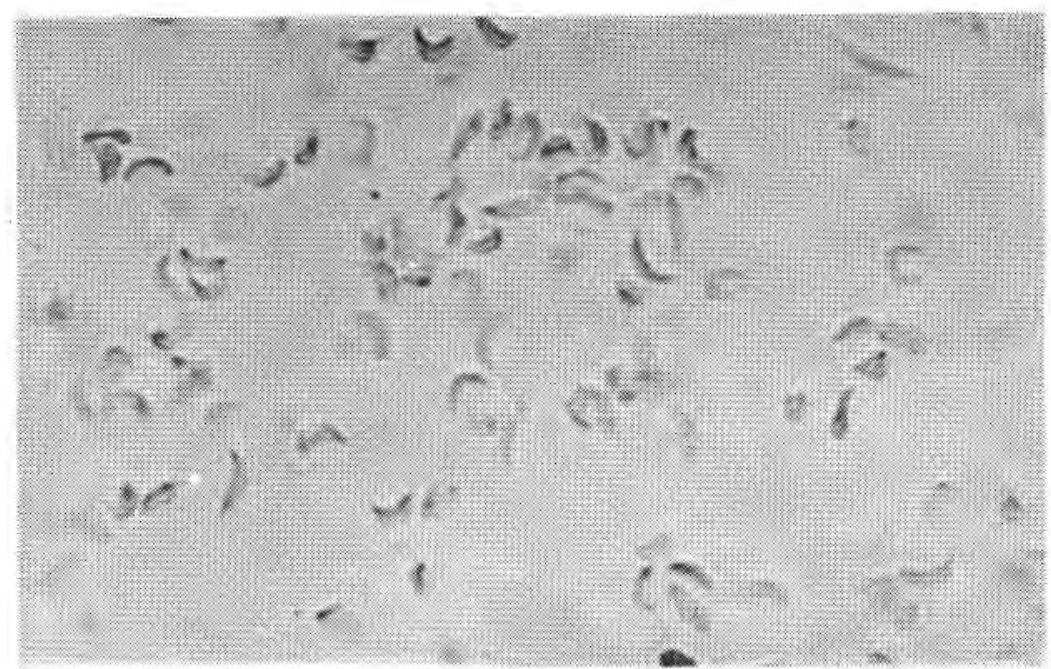

Resim 3. Orak hücre hastalığında oraklaşmış alyuvarlar*

* Mikroskopta (Nicon, S-Ke) $10 \times 100$ büyütmede, immersiyonla çekilmiştir. 


\section{Göbek Kordonu Kanları Üzerinde Yapılan Çalışmalar}

a. Hemolizatların hazırlanması:

Kordon kanı hemolizatları CROSBY ve HOUCHIN metodunun (13) bir modifikasyonu kullanılarak hazırlandı (7). Plazmalarundan kurtarilan konsantre alyuvarlar, iki kere \% 0.9 luk ve iki kere $\% 1.2$ lik sodyum klorür çözeltisi ile yıkandi, 1 hacım distile su ve 0.4 hacım toluen eklenerek en az yüzyirmi kere şiddetle çalkalanarak karıştırıldı. $4 \mathrm{C}^{\circ}$ de 18 saat bekletildi. Santrifüj edilerek, hücre artıkları ve toluen tabaklarından kurtarılarak berrak hemoglobin çözeltisi elde edildi.

b. Selüloz asetat elektroforezi:

Hemolizatlarda anormal hemoglobinlerin teşhisi için selüloz asetat elektroforezi kullanıldı (14). Kordon kanı hemolizatları, Sepraphore III (Gelman Instrument Company) selüloz poli asetat şeritleri kullanilarak Tris-disodyum EDTA-borik asit tamponunda ( $\mathrm{pH}: 8.9$ ), 350 voltta 3.5 saat elektroforezde yürütüldü. Ponceau-S boyası ile boyanarak yıkandı ve teşhisler yapıldı.

c. Fötal hemoglobin miktar tayini:

Hemolizatlarda SINGER alkali denatürasyon metodu ile fötal hemoglobin miktarları saptandı (15). Bir test tüpünde $1.6 \mathrm{mI} \mathrm{N} / 12$ potasyum hidrotsit çözeltisi $20 \mathrm{C}^{\circ}$ da uzun süre bekletildikten sonra üzerine $0.1 \mathrm{ml} \% 10$ konsantrasyondaki hemoglobin çözeltisi eklendi. Tam 1 dakika sonra $3.4 \mathrm{ml} \% 50$ doymuş amonyum sulfat çözeltisi eklenerek karıştırıldı. Çift katlı süzgeç kağıdından süzülerek, süzüntünün optik dansitesi spektrofotometrede $540 \mathrm{~nm}$ 'de ölçüldü. Buradan fötal hemoglobin miktarları hesaplandı.

\section{Kan proteinleri üzerinde yapılan çalışmalar}

a. Selüloz asetat elektroforezi :

369 kan plazmasinın bazik ortamda selüloz asetat elektroforezi yapıldı (16). Plazmalar, Sepraphore III (Gelman Instrument Company) selüloz poli asetat şeritlerinde, barbital tamponda ( $\mathrm{pH}: 8.6$ ), 350 voltta 1 saat süre ile elektroforezde yürütüldü. Amido-black 10 B boyası ile boyanarak yıkandı ve berraklaştırıldı. 
369 plazma üzerinde yapılan bu çalışmada bir çocukta "bisalbuminemi" karakteri görüldü.

b. Anormal albuminin miktar tayini:

Bisalbuminemi karakteri taşıdığı saptanan plazma örneğinde, anormal albuminin miktar tayini, elektroforegramlar optik dansitometrede okunarak yapıldı.

c. Jel filtrasyon:

Anormal albumin taşıyan plazma örneğinde albumin fraksiyonlarının ayırımı ve molekül ağırlığı tayini, jel filtrasyon yöntemi ile yapıldı (17). Sephadex G-200 (Pharmacia Fine Chemicals) jeli uygun ölçüde \% 9 luk sodyum klörür ile şişirildikten sonra $2.5 \times 40 \mathrm{~cm}$ boyutlarındaki kolona dolduruldu. Örnekler $5 \mathrm{mg} / \mathrm{ml}$ konsantrasyonda tatbik edilerek, Tris- $\mathrm{HCl}(\mathrm{pH}:$ 7.4) tamponu ile, üçer ml'lik fraksiyonlar halinde elüe edildi. Fraksiyonlar (Beckman Spectrofotometer DB-GT) $280 \mathrm{~nm}$ 'de optik dansiteleri ölçülerek miktar tayini yapildi.

d. Anormal albumin üzerinde genetik araştırma:

Teşhis edilen vaka üzerinde genetik araştırma yapıldı. Bunun için ailede hayatta olan ve kan almabilmesi mümkün olan 9 kişide, kan proteinleri ve anormal hemoglobinler araştırıldı. Tüm analizler yukarıda belirtilen metotlara göre yapıldı.

\section{BULGULAR}

1. 369 Eti Türkü üzerinde yapılan çalışmada yüksek oranda orak hücre karakteri saptandı, (Tablo I).

Tablo I. Köylerdeki orak hücre karakteri yoğunlukları.

$\begin{array}{lcc}\text { Köy } & \text { Ornek sayısı } & \text { Orak hücre karakteri (\%) } \\ \text { Adanalıŏlu } & 91 & 32.15 \\ \text { Karacailyas } & 126 & 12.70 \\ \text { Karaduvar } & 152 & 27.63\end{array}$

2. Saptanan orak hücre vakalarında, hemoglobin S'in hemoglobin A'ya oranı \% 20-48 arasinda saptand.

3. 369 kan örneğinde yalnız iki tane orak hücre anemisine rastland.. (Resim 1). 
4. Göbek kordonu kanları üzerinde yapılan analizler sonucu, 90 örnekten hiç birinde, hızlı göçeden hemoglobin variantları ve $\alpha$ talasemi hastalığ saptanmadı.

5. 369 kan plazmasının analizi sonucu bir kịside (A.Ç.) bisalbuminemi saptandl. Bulunan bu anormal albuminin bazik ortamda yapilan selüloz asetat elektroforezinde, normal albuminden daha hizlı göçettiği görüldü. (Resim 4). Bu albuminin normal albumine oranı optik dansitometre ile tayin edildiğinde bu oranın 49/51 olduğu görüldü. (Grafik 1). Saptanan bu anormal albumine "Albumin Mersin" adı verildi.

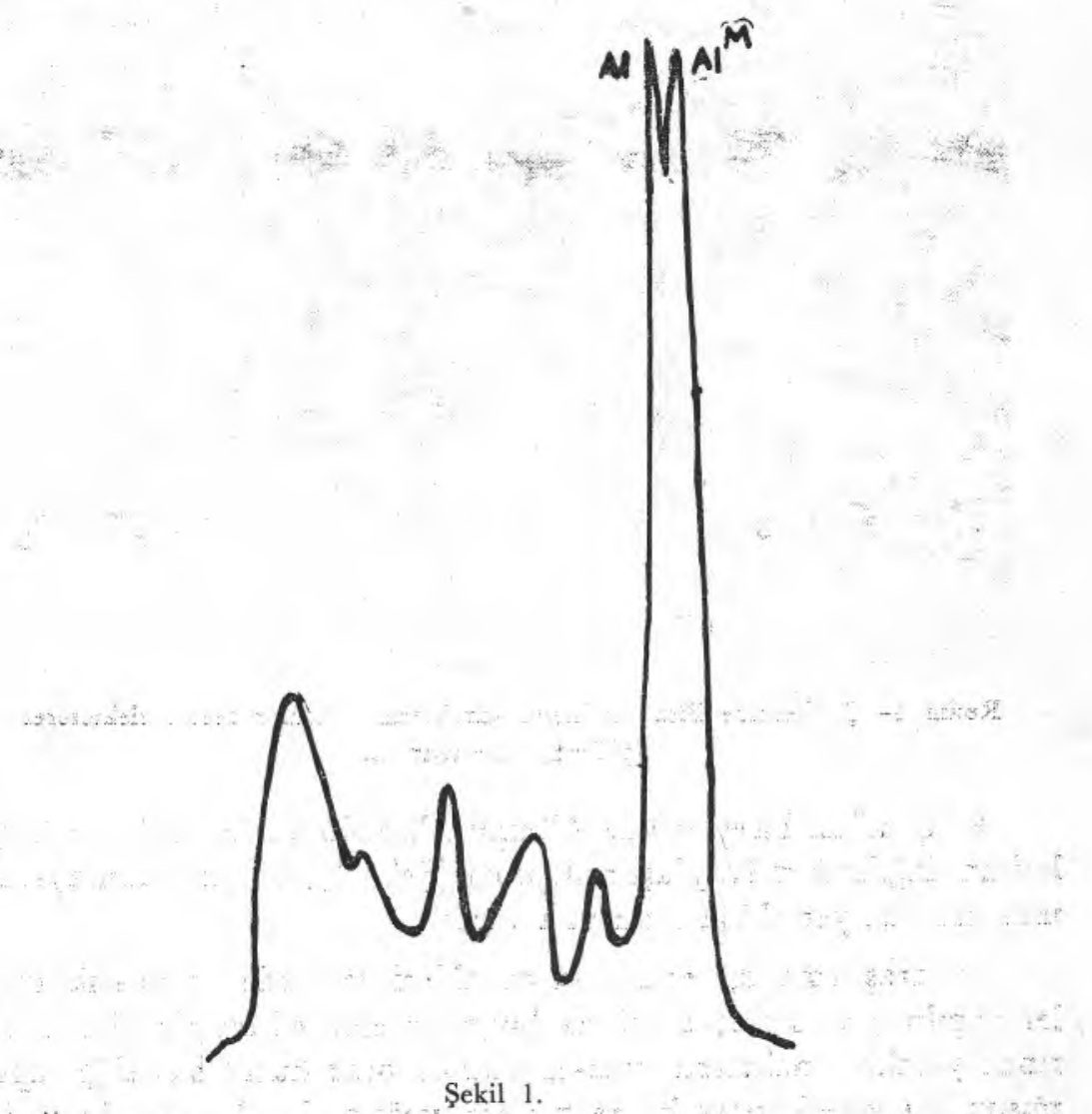

L. 6. Prosipitus (A.Ç.) üzerinde yapılan hemoglobin analizi aynı zamanda orak hücre karakteri taşidiğı da gösterdi. Böylece ilk kez 
bisalbuminemi ve orak hücre karakteri taşıyan bir vaka ortaya kondu.

7. Bu vakanın ailesi üzerinde yapılan genetik araştırma sonucu, bireylerde albumin Mersin ve hemoglobin S genlerinin dağılımları saptandı (Resim 4, 5). Bulgularımıza göre ailede yaşayan ve kan alınabilmesi mümkün olan bireylerde bu iki genin dağılımı Tablo 2'de verilmiştir.

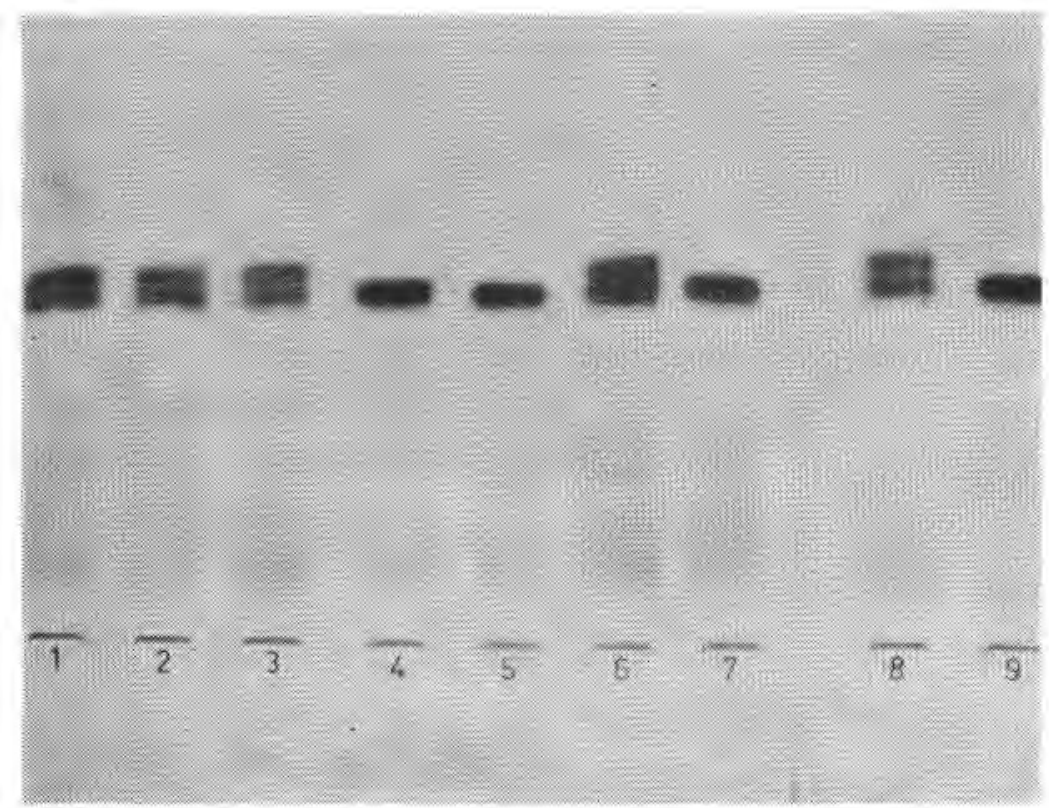

Resim 4- Ç ailesinde Bisalbüminemi karakterinin selüloz asetat elektoforezi $(\mathrm{pH}=8,6)$ ile ayırım.

8. Ç. ailesi bireylerinde Albumin Mersin ve hemoglobin S genlerinin dağılımları karşılaştırıldığında (Şekil 1), bu iki genin ayrı kromozomlarda yer aldığı sonucuna varıldı.

Bu araştırmada, çeşitli kan örnekleri üzerinde sistematik analizler yapılmış ve sonuçta değişik bulgular elde edilmiştir. Eti Türklerinde yapılan analizlerde yüksek oranda orak hücre hastalığı saptanmıstır. Bu yörede orak hücre geninin yoğun olarak bulunduğu daha önce yapılmış birçok çalışmada ortaya çıkmış ve sıklı̆̆ konusunda değişik oranlar verilmiştir (18-21). Karşılaştırma sonucu, tarafimız- 


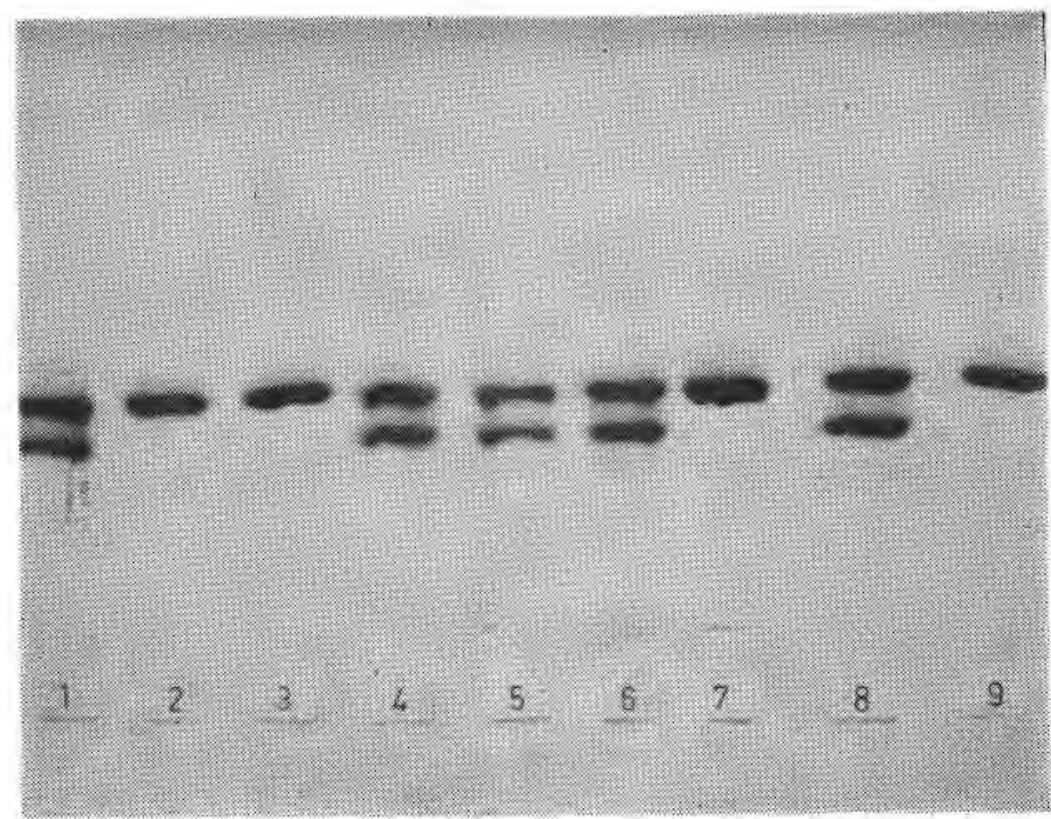

Resim 5- Ç ailesinde Orakhücre karakterinin selüloz asetat elektroforezi $(\mathrm{pH}=9,1)$ ile ayırımı

Tablo II. Ç. ailesi bireylerinde albumin ve hemoglobinlerin dağılımı

$\begin{array}{lll}\text { C. ailesi } & \text { Albumin } & \text { Hemoglobin } \\ \text { 1. A.Ç. } & \mathrm{Al}^{1}+\mathrm{A} 1^{\mathrm{M}} & \mathrm{A}+\mathrm{S} \\ \text { 2. F.Ç. } & \mathrm{A}^{1}+\mathrm{A} 1^{\mathrm{M}} & \mathrm{A} \\ \text { 3. A.Ç. } & \mathrm{Al}^{1}+\mathrm{A} 1^{\mathrm{M}} & \mathrm{A} \\ \text { 4. S.Ç. } & \mathrm{Al}^{1} & \mathrm{~A}+\mathrm{S} \\ \text { 5. R.Ç. } & \mathrm{Al}^{1} & \mathrm{~A}+\mathrm{S} \\ \text { 6. S.Ç. } & \mathrm{Al}^{1}+\mathrm{A} 1^{\mathrm{M}} & \mathrm{A}+\mathrm{S} \\ \text { 7. F.Ç. } & \mathrm{Al}^{1} & \mathrm{~A} \\ \text { 8. A.Ç. } & \mathrm{Al}^{1}+\mathrm{A} 1^{\mathrm{M}} & \mathrm{A}+\mathrm{S} \\ \text { 9. H.Ç. } & \mathrm{A} 1^{1} & \mathrm{~A}\end{array}$

dan saptanan gen yoğunluklarının genellikle daha yüksek olduğu görülmektedir. Bulgularımızdan anlaşıldığına göre, Eti Türkü populasyonunun içinde, gen yoğunluğunun çok yüksek olduğu bazı odak noktaları vardır. Bu bölgelerde gen yoğunlukları çok artmakta ve hatta Afrika'da saptanan oranlara ulaşılmaktadır. Köylerdeki kapalı yaşayış biçimi de genin seyrelmesine olanak vermemekte ve yoğunlaşma üzerinde diğer bir etken olarak görünmektedir. 


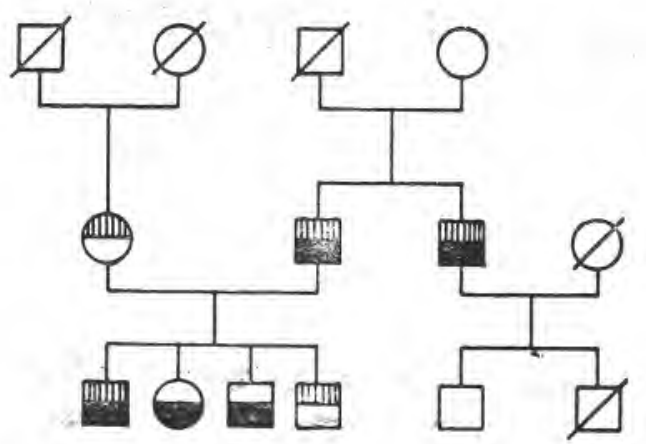

Sekil 2. C, ailesi bireylerinde albumin Mersin ve Hemoglobin S genlerinin dağılım .

$\square \bigcirc$ : Normal, $\square \bigcirc$ : bisalbumin, $\square @$ 盂而: Hb s karakteri

Ayrıca bu araştırmada Türkiye'de ilk kez hızlı göç eden bir anormal albumin varyantı bulunmuştur. Böylece dünyada çok ender olarak görülen albumin anomalilerinden (22-23) birisinin de ülkemizde olduğu saptanmıştir.

Saptanan bu vakanın aynı zamanda orak hücre karakteri taşıdı$\breve{\text { ğ}} 1$ anlaşılmışır. Böylece ilk kez bu iki genetik bozukluğu birlikte taşıyan bir vaka ortaya konmuştur. Wieme, bisalbuminemiyi olusşturan genetik bozukluğun, orak hücre hastalığına sebep olan bozukluğa benzer olduğunu ileri sürmüş̧ür (24). Bu bakımdan, oluşumları aynı mekanizmaya bağlı olduğu ileri sürülen bu iki genetik hastalığın aynı kişide saptanabilir olması, Wieme'nin hipotezini doğrular niteliktedir.

Vakanın aile bireylerinde, orak hücre ve Albumin Mersin geninin dağılımları karşılaştırıldığında, bu iki genin ayrı kromozomlarda yer aldığı sonucuna varılmıştır.

ÖZET

Hemoglobinopatiler, dünyada yaygın olarak bulunan ve belirli etnik gruplara özgü kalıtsal hastalıklardır. Türkiye, coğrafik konumu ve tarihi özellikleri nedeniyle, dünyanın çeşitli bölgelerinde saptanan hemoglobinopatilerin hemen hemen tümünün örneklerini içinde ba- 
rındıran sayılı ülkelerden biridir. Ülkemizde bu hastalıkların dağılım ve kaynaklarının araştırılması özel bir önem taşımaktadır.

Bu çalı̧̧mada, Türkiye'de çeşitli kaynaklardan elde edilen kan örnekleri üzerinde sistematik bir hemoglobinopati araştırması yapılmiştır. Bu amaçla İçel yöresindeki üç Eti Türkü köyünde 7-11 yaş grubundaki 369 çocuktan alınan kan örnekleri ve Ankara Doğumevinden sağlanan 90 göbek kordonu kanı üzerinde çalışılmışıı. Ayrıca 369 Eti Türkünün kan proteinleri araştırılmıștır. Bütün analizler bir mikrometotlar dizisi ile yürütülmüş, ayrıca çalışma koşullarımıza uygun bir mikrohemoliz yöntemi geliştirilmiştir.

Araştırma sonucu, üç Etì Türkü köyünde yüksek oranda orak hücre hastalığı saptanmıştır. Orak hücre karakteri yoğunluğu, Adaloğlu köyünde \% 32.15, Karacailyas köyünde \% 12.70, Karaduvar köyünde \% 27.63 olarak bulunmuştur. Göbek kordonu kanları üzerinde yapılan analizler sonucu anormal hemoglobine rastlanmamıstir.

369 Eti Türkünün kan proteinleri analizi sonucu bir bisalbuminemi vakası saptanmıştır. Bu anormal albuminin, süratli yürüyen bir albumin varyantı olduğu ortaya konmuş ve buna "Albumin Mersin" adı verilmiştir. Prosipitusun kan hemoglobini analizi, aynı zamanda orak hücre karakteri taşıdığını ortaya koymuştur. Albumin Mersin ve hemoglobin S genlerinin aile bireylerindeki dağılımları, bu iki genin ayrı kromozomlarda yer aldığı kanısını vermiştir.

\section{SUMMARY}

Hemoglobinopathies are hereditary disorders which are rather wide spread over certain areas of the world and characteristic for some of the ethnic communities. Turkey, because of its geographical location and historical inheritance, is one of few countries where almost all kinds of hemoglobinopathies exist. For this reason examination of the distribution and origins of these disorders in our country is specially important.

In our research work, a systematic investigation of various hemoglobinopathies carried out on blood samples collected from different sources in Turkey. Hemoglobin analysis were made on blood samples of 369 children between 7-11 living in three villages inhabited 
by Eti Turks in the Içel region, south of Turkey, and 90 cord blood samples obtained from Ankara Maternity Hospital. In addition, blood plazma proteins of 369 Eti Turks were examined. All the analysis have been carried out using a series of micro methods, meanwhile we have developed a micro hemolysis method which was appropriate for our working conditions.

A high frequency of sickle cell disease was observed in the villages. Incidence of sickle cell trait was $32.15 \%$ in Adanalığlu village, $12.15 \%$ in Karacailyas and $26.63 \%$ in Karaduvar . Only two sickle cell anemia cases were found in 369 individuals. But no abnormal hemoglobin was obtained from the 90 cord blood samples.

During the analysis of 369 blood samples, a bisalbuminemia case was also detected. This abnormal albumin was shown to be a fast moving albumin variant and named by ourselves as "Albumin Mersin". The analysis of blood hemoglobins of the prosipitus indicate that he was also carrying the sickle cell trait. Distribution of sickle cell and bisalbuminemia genes of the other individuals from the family was investigated. Their distribution among the members of the family, suggested that these two genes might be located on different chromosomes.

\section{LITERATÚR}

1. Çavdar, A.O., International Symposium on Abnormal Hemoglobins and Thalasemia, Abstract Book, 48, (1974).

2. Aksoy, M., Nature, 193, 786, (1962).

3. Lehman, H., Huntsman, R.G., -Man's Haemoglobins, North-Holland Publishing Company, Amsterdam, (1974).

4. Thrahim, S.A., Barakat, S.M., Acta Haemat., 44, 287, (1970).

5. Aksoy, M., t.U. Tip Fak.Mec., 31, 1, (1968).

6. Giorgio, A.J., Clin Chim. Acta, 27, 362, (1970).

7. Holtz, A.H., Bibl. Haemat., 21, 75, (1965).

8. Grahan, J.L., Capt, M.C., Grunbaum, B.W., Am. J. Clin. Pathol., 39, (6), 567, (1963).

9. Orsini, A., Vovan, L., Perrimond, H., Pediatrie, 25 (3), 391, (1970).

10. Robinson, A.R., Robson, M., Harrison, A., Zuelzer, W., 7. Lab. Clin.Med., 50, 745 , (1957).

11. Chernoff, A.I., Pettit, N.M., tbid 63 (2), 290, (1964).

12. Daland, G.A., Castle, W.B., Ibid, 33, 1082, (1948). 
13. Crosby, W.G., Houchin, D.N., Blood, 12, 1132, (1957).

14. Grunbaum, B.W., Lyons, M.F., Carroll, M.V., Zec, L., Microchem 7.7 (1), 54, (1963).

15. Singer, K., Chernoff, A. I., Singer, L., Blood, 6, 413, (1951).

16. Block, R.J., Durrum, E.L., Zweig, G. -Paper Chromatograpy and Electro-phoresis, Academic Press Inc., New-York (1958).

17. Bingöl, G., Ankara Ecz. Fak. Mec., 3, 136, (1973).

18. Aksoy, M., Lancet, 1, 589, (1955).

19. Aksoy, M., Blood, 17, 657, (1961).

20. Altay, Ç., Yetkin, S., Özsoylu, Ş., International Symposium on Abnormal Hemoglobins and Thalassemia, Abstract Book, 26, (1974).

21. Özsoylu, Ş.., Şahinoglu, M., ibid., 28 -(1974).

22 . Weitkamp, L,R., Salzano, F.M., Neel, J.V., Porta, F., Geerdink, R.A., Tarnoky, A.L., Ann. Hum. Genet., 36, 381 (1973).

23. Weitkamp, L.W., ibid. 37, 511, (1973).

24. Wieme, R.J., Clin. Chim. Acta, 5, 443, (1960). 